
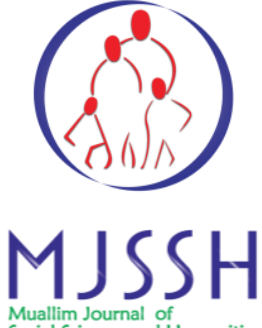

Social Science and Humanities

\title{
INDIAN WOMEN STATUS: A HISTORICAL
} PERSPECTIVE

\author{
G.Paranthaman ${ }^{1}$ \\ S.Santhi ${ }^{2}$ \\ R.Radha ${ }^{3}$ \\ G.Poornima Thilagam ${ }^{4}$
}

${ }^{1}$ Assistant Professor, Department of History, Alagappa University, Karaikudi, India. Email : paranthamang@alagappauniversity.ac.in

${ }^{2}$ Teaching Assistant, Department of History, Alagappa University, Karaikudi, India. Email: drbsr178alu@gmail.com

${ }^{3}$ Teaching Assistant, Department of History, Alagappa University, Karaikudi, India. Email: dr.r.radha@gmail.com

${ }^{4}$ Teaching Assistant, Department of History, Alagappa University, Karaikudi, India. Email: poornimaachiever@gmail.com

DOI: https://doi.org/10.33306/mjssh/19

\section{Abstract}

Woman constitutes the key role in the Indian society. Women in ancient India enjoyed high status in society and their condition was good. The Ancient and medieval status of women in modern Indian society regarding Equality, Education, Marriage and Family life, Race and Gender, Religion and Culture is maintained or deteriorated. The Vedic women had economic freedom. Some women were engaged in teaching work. Home was the place of production. Spinning and weaving of clothes were done at home. Women also helped their husbands in agricultural pursuit. In the religious field, wife enjoyed full rights and regularly participated in religious ceremonies with her husband. Religious ceremonies and sacrifices were performed jointly by the husband and wife. Women even participated actively in religious discourses. The status of women improved a little during the Buddhist period though there was no tremendous change. The role of women in Ancient Indian Literature is immense. Ancient India had many learned ladies. The Medieval period (Period between 500 A.D to 1500 A.D) proved to be highly disappointing for the Indian women, for their status further deteriorated during this period. Through this study we come to the conclusion that as the women has equal participation in human development. She is half of the human race. But she lacks in society. Women are not treated with respect as in the Ancient Indian society. Lot of crime against women is seen in the modern society. The Constitutional provisions are not sufficient to get the 
respectable position in society. The paper will help us to imagine the participation of women in social, religious, economic and household matters from Ancient to Modern.

Keywords: Equality, pursuit, ceremony, sufficient, deteriorate

This article is licensed under a Creative Commons Attribution-Non Commercial 4.0 International License

Received $20^{\text {th }}$ Febryary 2019, revised $8^{\text {th }}$ March 2019, accepted $25^{\text {th }}$ March 2019

\section{Introduction}

Women constituted the key role in the arch of Indian society. No doubt the Rig Vedic Women in India enjoyed high status in society and their condition was good. Even the women were provided opportunity to attain high intellectual and spiritual standard. But from enjoying free and esteemed positions in the Rig-Vedic society, women started being discriminated since the LaterVedic period in education and other rights and facilities (Saravanakumar, 2016) ${ }^{1}$. Indian society doubts that we are in the midst of a great revolution in the history of women. The voice of women is increasingly heard in Parliament, courts and in the streets. While women in the West had to fight for over a century to get some of their basic rights, (Altekar,1983) ${ }^{2}$ like the right to vote, the Constitution of India has given women equal rights with men from the beginning (Devandra,Kiran, 1985) ${ }^{3}$. The Ancient and medieval status of women in modern Indian society regarding Equality, Education, Marriage and Family life, Race and Gender, Religion and Culture is maintained or deteriorated. This paper also intends to give an awareness and insight into the problems faced by women over the years and their role. The paper will help us to imagine the participation of women in social, religious, economic and household matters in the ancient times.

The Rig Vedic Women in India enjoyed high status in society. During the Vedic Age wife was put in an esteemed position. She was considered as half of the man, his trust friend, companion in solitude, father in advice and the rest in passing the wilderness of Life. The women were provided opportunity to attain high intellectual and spiritual standard. There were many women Rishis during this period. Though monogamy was mostly common, the richer section of the society indulged in polygamy. There was no sati system or early marriage. But from enjoying free and esteemed positions in the Rig-Vedic society, women started being discriminated since the Later-Vedic period in education and other rights and facilities. Child marriage, widow burning or sati, the purdah and polygamy further worsened the women's position The Indian cultural tradition begins with the Vedas. It is generally believed that the Vedic period is spread over from 2000 BC to 500 B.C. Some general observations discussed in 
this paper regarding the status of women during this vast period. (Altekar, 1983) ${ }^{2}$ Vedic women had economic freedom. Some women were engaged in teaching work. Home was the place of production. Spinning and weaving of clothes were done at home. Women also helped their husbands in agricultural pursuits.

\section{Property Rights in Inheritance}

Women rights were very much limited in inheriting property. A married daughter had no share in her father's property but each spinster was entitled to one-fourth share of patrimony received by her brothers. Women had control over gifts and property etc. Received by a woman at the time of marriage but the bulk of the family property was under the control and management of the patriarch. As a wife, a woman had no direct share in her husband's property. However, a for second wife was entitled to 1/3rd of her husband's wealth. A widow was expected to lead an ascetic life and had no share in her husband's property (Sharma Rathakrishna, 1981) ${ }^{4}$. Thus it could be generalized that the social situation was not in favour of women possessing property and yet protection was given to them as daughters and wives.

\section{Women Role in the Religious Field}

In the religious field, wife enjoyed full rights and regularly participated in religious ceremonies with her husband. Religious ceremonies and sacrifices were performed jointly by the husband and wife. Women even participated actively in religious discourses. The role of Women in Public Life that could shine as debaters in public assemblies (Krishnaraj, Maithveyi, $1986)^{5}$. They usually occupied a prominent place in social gatherings but they were denied entry, into the "Sabhas" because these places besides being used for taking political decisions were also used for gambling, drinking and such others purposes. Women's participation in public meetings and debates, however, became less and less common in later Vedic period.

\section{Status of women during the Epic period}

The women of Epic India enjoyed a honorable position at home. Both Ramayana and Mahabharata Epics had given a respectable place for women; women had been called the root of Dharma, prosperity in the epics. We find vast references of the expression of courage, strong will power and valour of women like Kaikeye, Sita, Rukmani, Satyabhama, Savitri, Draupadi and others. The Ramayana is a glorious illustration for the Hindu ideal woman hood, it glorifies the value of "Pativratya" and idealises womanhood as one of the most venerable aspects of our heritage (Chaturvedi, Geeta 1985) ${ }^{6}$. The Mahabharata also outlines the attitude of the wife to husband. The Women during the Period of Dharmashatras and Puranas the status of women gradually declined and underwent a major change. The girls were deprived of formal education. 
Daughters were regarded as second class citizens. Freedom of women was curtailed. The women were prevented from learning the Vedas and becoming Brahma charinis. The law giver of Indian society gave the statement that women have to be under father during childhood, under her husband during youth and under her son during old age. Shall she deserve freedom? (Saravanakumar, 2017) ${ }^{7}$.

\section{Women in the Buddhist Period}

The status of women improved a little during the Buddhist period though there was not tremendous change. Some of the rigidities and restrictions imposed by the caste system were relaxed. Buddha preached equality and he tried to improve the cultural, educational and religious statuses of women. During the benevolent rule of the famous Jain and Buddhist kings such as Chandragupta Maurya, Ashoka, Kanishka, Sri Harsha and others, women regained a part of their lost freedom and status due to the relatively broad minded Buddhist and Jain philosophy $(\text { Sen, } 1988)^{8}$. Women were not only confined to domestic work but also they could resort to an educational career if they so desired. In the religious field women came to occupy a distinctly superior place. Women were permitted to become "Sanyasis". Many women took a leading role in Buddhist monastic-life, women had their sangha called the BhikshuniSangha, which was guided by the same rules and regulations as these of the monks. The sangha opened to them avenues of cultural activities and social service and ample opportunities for public life. Their political and economic status however remained unchanged.

\section{Status of women in the Medieval India}

The Medieval period (Period between 500 A.D to 1500 A.D) proved to be highly disappointing for the Indian women, for their status further deteriorated during this period. Medieval India was not women's age it is supposed to be the 'dark age' for them. When foreign conquerors, the Muslims invaded India they brought with them their own culture. For them women was the sole property of her father, brother or husband and she does not have any will of her own. This type of thinking also crept into the minds of Indian people and they also began to treat their own women like this. One more reason for the decline in women's status and freedom was that original Indians wanted to shield their women folk from the barbarous Muslim invaders. As polygamy was a norm for these invaders they picked up any women they wanted and kept her in their "harems". In order to protect those Indian women started using 'Purdah', (a veil) (Dutt, 1937) ${ }^{9}$. They were not allowed to move freely and this led to the further deterioration of their status. These problems related with women, resulted in changed mindset of people. Now, they began to consider a girl as misery and a burden, which has to be shielded from the eyes of intruders. Thus a vicious circle started in which women was at the receiving end. All this gave rise to some new evils such as Child Marriage, Sati, Jauhar and restriction on girl education. 


\section{Restriction on Women Marriage}

It was a norm in medieval India. Girls were married off at the age of 8-10.They were not allowed access to education and were treated as the material being. The plight of women can be imagined by one of the shloka of Tulsidas where he writes "Dhol, gawar, shudra, pashu, nari, and sabtadan keadhikari". Meaning that animals, illiterates, lower castes and women should be subjected to beating. Thus women were compared with animals and were married off at an early age. The child marriage along with it brought some more problems such as increased birth rate, poor health of women due to repeated child bearing and high mortality rate of women and children. The veil or the 'Purdah' system was widely prevalent in medieval Indian society (Menon Indu, 1989 $)^{10}$. It was used to protect the women folk from the eyes of foreign rulers who invaded India in medieval period. But this system curtailed the freedom of women. It is also more or less similar to Sati but it is a mass suicide. Jauhar was prevalent in the Rajput societies. In this custom wives immolated themselves while their husband was still alive (Nanda, 1976) ${ }^{11}$. When people of Rajput clan became sure that they were going to die at the hands of their enemy then all the women arrange a large pyre and set themselves afire, while their husband used to fight the last decisive battle known as "Shaka", with the enemy. Thus protecting the sanctity of the women and the whole clan. The ritual of dying at the funeral pyre of the husband is known as "Sati" or "Sahagaman". According to some of the Hindu scriptures women dying at the funeral pyre of her husband go straight to heaven so it's good to practice this ritual. Initially it was not obligatory for the women but if she practiced such a custom she was highly respected by the society. Sati was considered to be the better option than living as a widow as the plight of widows in Hindu society was even worse. The condition of widows in medieval India was very bad. They were not treated as human beings and were subjected to a lot of restrictions. They were supposed to live pious life after their husband died and were not allowed entry in any celebration. Their presence in any good work was considered to be a bad omen. Sometimes heads of widows were also shaved down. They were not allowed to remarry. Any woman remarrying was looked down by the society. This cruelty on widows was one of the main reasons for the large number of women committing Sati (Cormak, 1953) ${ }^{12}$. In medieval India living as a Hindu widow was a sort of a curse. It's a serious issue. Courts are flooded with cases related to death due to dowry harassment by husband and in laws. In ancient times women were given 'Stridhan' when they departed from the house of their parents. This amount of money was given to her as a gift which she can use on her and her children but her in-laws did not have any right on that amount. This amount was supposed to help the girl in time of need. Slowly this tradition became obligatory and took the form of dowry. Nowadays, parents have to give hefty amount in dowry, the in laws of their girl are not concerned whether they can afford it or not. If a girl brings large amount of dowry she is given respect and is treated well in her new home and if she does not bring dowry according to expectations of her in laws then she has to suffer harassment. Due to this evil practice many newly wedded women of India have to lose their lives. 


\section{Women Education in Ancient and Modern Age}

The role of women in Ancient Indian Literature is immense. Ancient India had many learned ladies. There were two types of scholarly women the Brahmavadinis or the women who never married and cultured the Vedas throughout their lives; and the Sadyodva has who studied the Vedas till they married. Panini mentioned of female students' studying Vedas. Katyana called female teachers Upadhyaya or Upadhyayi. Ashoka got his daughter, Sanghamitra, inducted into preaching Buddhism. From the Jain texts Buddhist nuns composed hymns. Women did write Sanskrit plays and verses, excelled in music, painting and other fine arts (Saravanakumar, 2016) ${ }^{1}$. The girls of medieval India and especially Hindu society were not given formal education. They were given education related to household chores. But a famous Indian philosopher 'Vatsyayana' wrote that women were supposed to be perfect in sixty four arts which included cooking, spinning, grinding, knowledge of medicine, recitation and many more. The Ancient Women in Politics often enjoyed prominent roles (Saravanakumar, 2016) ${ }^{1}$. Megasthenes mentioned the Pandiya women running the administration. The Satavahana queen, "Nayanika ruled the kingdom on behalf of her minor son. So did Pravabati, daughter of Chandragupta II, on behalf of the minor Vakataka prince. A little after the Gupta period, queens used to rule in Kashmir, Orissa and Andhra. Princess Vijaybhattarika acted as the provincial ruler under the Chalukyas King; Vikramaditya I. Women were provincial and village administrators in the Kannada region.

\section{Batter status of women in Southern India comparatively Northern India}

The status of women in Southern India was better than in the North India. While in Northern India there were not many women administrators, in Southern India we can find some names that made women of that time proud. Priyaketaladevi, queen of Chalukyas Vikramaditya ruled three villages. Another woman named Jakkiabbe used to rule seventy villages. In South Indian women had representation in each and every field. Domingo Paes, famous Portuguese traveler testifies to it. He has written in his account that in Vijayanagara kingdom women were present in each and every field. Nunez, another famous traveler to the South also agrees to it and says that women were employed in writing accounts of expenses, recording the affairs of kingdom, which shows that they were educated. There is no evidence of any public school in northern India but according to famous historian IbnBatuta there were 13 schools for girls and 24 for boys in Honavar. There was one major evil present in South India of medieval time. But it was the custom of Devadasis (Clark, Alice, 1987) ${ }^{13}$. Devadasis was a custom prevalent in Southern India. In this system girls were dedicated to temples in the name of Gods and Goddesses. The girls were then onwards known as 'Devadasis' meaning servant or slave of God. These Devadasis were supposed to live the life of celibacy. All the requirements of Devadasis were fulfilled by the grants given to the temples. In temples they used to spend their time in the worship of God and by singing and dancing for the God. Some kings to invite temple dancers to perform at their 
court for the pleasure thus some Devadasis converted to Rajadasis prevalent in some tribes of South India.

\section{Women's Struggle and Reforms}

Though women of India are not at par with her counterpart in Western world but she is struggling hard to make her mark in men's world (Desai, Neera, 1977) ${ }^{14}$. There have been social reformers like Raja Ram Mohan Roy, Ishwar Chandra Vidyasagar, Swami Vivekananda, and Swami Dayananda Saraswati who have helped women gain their previous status in society.

Raja Ram Mohan Roy was strictly against the evils prevalent in society in his time. He is the one who has done women a great favour by abolishing Sati lawfully. He himself married a widow thus setting the example for the whole society. Along with 'Dwarka Nath Tagore' he founded "Brahma Samaj" for the reform of Indian society and emancipation of women.

Ishwar Chandra Vidyasagar was popularly known as Vidyasagar, which means sea of Knowledge. He was a pillar of social reform movement of Bengal in the 19th century. He strongly supported women education in Bengal and went door to door to persuade people to send their girl child to school. He also did a lot in the field of widow remarriage (Forb, Geraldine, 1998) ${ }^{15}$. He opened many schools for girls.

Jyotirao Govindrao Phule was a real philanthropist. He was the one to open first girl school in India. He is also credited with opening first home for widows of the upper caste and a home for newborn girl children so that they can be saved from female infanticide.

Swami Dayananda Saraswati was the founder of Arya Samaj and gave a cry, "back to Vedas". He translated Vedas from Sanskrit to Hindi so that a common man can read it and understand the Vedic Hindu scriptures gave utmost importance to women (Sharma, Radakrishna, $1981)^{4}$. He emphasized for the equal rights for women in every field. He tried to change the mind-set of people with his Vedic teachings.

\section{Conclusion}

The women were provided opportunity to attain high intellectual and spiritual standard. But from enjoying free and esteemed positions in the Rig-Vedic society, women started being discriminated against since the Later-Vedic period in education and other rights and facilities. Indian society doubt that we are in the midst of a great revolution in the history of women. The voice of women is increasingly heard in Parliament, courts and in the streets. The Ancient and medieval status of women in modern Indian society regarding Equality, Education, Marriage and Family life, Race and Gender, Religion and Culture is maintained or deteriorated. The Rig 
Vedic Women in India enjoyed high status in society. The women were provided opportunity to attain high intellectual and spiritual standard. In Vedic India, women did not enjoy an inferior status rather they occupied an honorable place. They had ample rights in the social and the religious fields and limited rights in the economic and the political fields. They were not treated as inferior or subordinate but equal to men. We have honored our country as our Motherland "Bharat Mata" and our nationalism has grown up from the seed Mantra "Vande Mataram". Positions of women in society are the index to the standard of social organization. Through this study we come to the conclusion that the women have equal participation in human development. She is half of the human race. But she lacks in society. Women are not treated with respect as in the Ancient Indian society. Lot of crime against women is seen in modern society. Constitutional provisions are not sufficient to get the respectable position in society. Some certain changes inside mind-set of women as well as man are required.

\section{ACKNOWLEDGEMENT}

This article has been written with the financial support of RUSA-Phase 2.0 grant sanctioned vide LetterNo.F.24-5112014-U,Policy (TN Multi-Gen), Dept.of Edn, Govt of India, Dt.09.10.2018.

\section{References}

1. Saravanakumar, A. R. (2016). Present scenario of women's education in India. In a National Seminar sponsored by ICHR on Educational Practices in Chola Kingdom (850 1279 AD) EPICK - 2016 organized by Department of History \& DDE, Alagappa University, Karaikudi.

2. Altekar, A. S. (1983). Position of women in Hindu Civilization. Banaras: The Culture publication House, Banaras Hindu University.

3. Devandra, Kiran. (1985). Status and position of women in India. With Special Reference to Women in Contemporary India. New Delhi: Shakti Books.

4. Sharma, Radakrishna. (1981). Nationlism, Social Reform and Indian Women. New Delhi: Janaki Prakashan.

5. Krishnaraj, Maithveyi. (1986). Women's studies in India. Bombay Popular Prakasham.

6. Chaturvedi, Geeta (1985). Women administration in India. Jaipur: RBSA Publication.

7. Saravanakumar, A. R. (2017). Difference between human rights and fundamental rights. In two day National Conference on Human Rights Education: (NCHRE - 2017) organized by Department of Education, Alagappa University, Karaikudi.

8. Sen, S. N. (1988). Ancient Indian history and civilization. New Delhi: Wiley Eastern Limited.

9. Dutt, M. N. (1937). Status of women. Calcutta: Mohendra Publishing Committee. 
10. Menon, Indu, M. (1989). Status of Muslim women in India. A case study of Kerala. New Delhi: Uppal Publishing House.

11. Nanda, B. R. (1976). Indian women from purdha to modernity. New Delhi: Vikas Publications.

12. Cormack, M. (1953). The Hindu women. Bombay: Asia Publishing House.

13. Clark, Alice. (1987). Social demography of excess female mortality in India : New directions. In Economic and Political Weekly, 22(17), 12-21.

14. Desai, Neera. (1977). Women in modern India. Mumbai: Vora Company.

15. Forb, Geraldine. (1998). Women in modern India, Cambridge University: Replica 233 Press.

\section{Citation}

Paranthaman, G., Santhi, S., Radha, R., \& Poornima Thilagam, G. (2019). Indian women status: A historical perspective. Muallim Journal of Social Science and Humanities, 3(2), 258-266. https://doi.org/10.33306/mjssh/19 